University of Arkansas, Fayetteville

ScholarWorks@UARK

Education Reform Faculty and Graduate

Students Publications

$1-24-2017$

\title{
Who is More Free? A Comparison of the Decision-Making of Private and Public School Principals
}

\author{
M. Danish Shakeel \\ University of Arkansas, Fayetteville, mdshakee@uark.edu \\ Corey A. DeAngelis \\ University of Arkansas, Fayetteville
}

Follow this and additional works at: https://scholarworks.uark.edu/edrepub

Part of the Educational Assessment, Evaluation, and Research Commons, Educational Leadership Commons, and the Other Educational Administration and Supervision Commons

\section{Citation}

Shakeel, M. D., \& DeAngelis, C. A. (2017). Who is More Free? A Comparison of the Decision-Making of Private and Public School Principals. Education Reform Faculty and Graduate Students Publications. Retrieved from https://scholarworks.uark.edu/edrepub/31

This Article is brought to you for free and open access by the Education Reform at ScholarWorks@UARK. It has been accepted for inclusion in Education Reform Faculty and Graduate Students Publications by an authorized administrator of ScholarWorks@UARK. For more information, please contact scholar@uark.edu. 


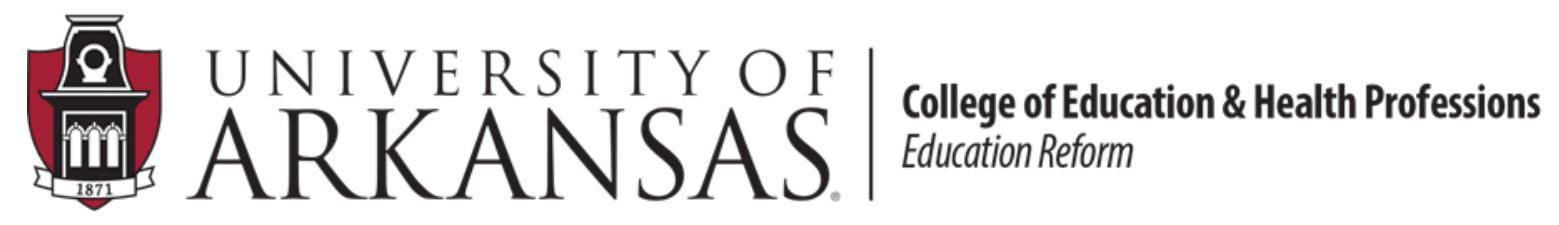

\title{
WORKING PAPER SERIES
}

\section{Who is More Free? A Comparison of the Decision-Making of Private and Public School Principals}

\author{
M. Danish Shakeel \\ Corey A. DeAngelis
}

Last Revised: January 24, 2017

EDRE Working Paper 2016-09

The University of Arkansas, Department of Education Reform (EDRE) working paper series is intended to widely disseminate and make easily accessible the results of EDRE faculty and students' latest findings. The Working Papers in this series have not undergone peer review or been edited by the University of Arkansas. The working papers are widely available, to encourage discussion and input from the research community before publication in a formal, peer reviewed journal. Unless otherwise indicated, working papers can be cited without permission of the author so long as the source is clearly referred to as an EDRE working paper. 


\title{
WHO IS MORE FREE? A COMPARISON OF THE DECISION-MAKING OF PRIVATE AND PUBLIC SCHOOL PRINCIPALS
}

\author{
M. Danish Shakeel \\ Department of Education Reform, \\ University of Arkansas \\ mdshakee@uark.edu \\ Corey A. DeAngelis \\ Department of Education Reform, \\ University of Arkansas \\ cadeange@uark.edu
}

January 24, 2017

School Choice Demonstration Project,

University of Arkansas, Fayetteville, AR

\section{Acknowledgements}

The content of the report is solely the responsibility of the authors and does not necessarily represent the views of the University of Arkansas. Corresponding author is M. Danish Shakeel, mdshakee@uark.edu. 


\begin{abstract}
While an abundance of school choice literature focuses on student achievement outcomes, little has been done to determine the mechanisms involved in producing such outcomes. We present a comparative analysis of private and public school principals using data from the School and Staffing Survey (SASS) 2011-2012. We add to the literature by examining the differences in private and public school principals' abilities to influence important decisions at their schools. We conclude that private schooling may have a systematic advantage over public schooling since private school leadership exhibits more autonomy in influencing relevant decisions.

Keywords: school choice; school leadership; school management; School and Staffing Survey
\end{abstract}




\section{Introduction}

"While the public school principal is bound most by red tape, the private school principal is bound most by his or her conscience."

\section{—John E. Chubb and Terry M. Moe, 1988, p. 1076}

School choice has emerged as a key intervention in school reform globally. In fact, the United States President-Elect, Donald Trump, promised massive expansion of private school choice through a reallocation of $\$ 20$ billion in federal funding in 2017 . Evidence suggests that private schools slightly outperform public schools on improving student achievement within the US as well as internationally (Betts \& Tang, 2011; Forster, 2016; Greene, 2005; Shakeel, Anderson, \& Wolf, 2016; Tooley, 2005; Tooley, Bao, Dixon, \& Merrifield, 2011). Most of the school choice studies focus on student achievement (West \& Woessmann, 2010; Witte, 2001; Witte et al., 2014; Wolf et al., 2013). Out of the nineteen experimental studies of private school choice in the United States, the only negative findings for test scores were from the two studies of the Louisiana Scholarship Program (Abdulkadiroglu, Pathak, \& Walters, 2015; Mills \& Wolf, 2016).

Other studies have examined impacts on the long-term outcomes of students such as attainment (Booker et al., 2008; Zimmer, 2009; Cowen et al., 2013; Wolf et al., 2013) and criminal activity (Deming, 2011; Dobbie \& Fryer, 2015; DeAngelis \& Wolf, 2016). While this evidence is limited, the existing studies have found that access to school choice reduces criminal activity and teen pregnancy while increasing the likelihood of graduating from high school. Additionally, access to private school choice may increase performance in public schools through competitive effects (Egalite, 2013; Egalite, 2016; Figlio \& Hart, 2014; Greene \& Winters, 2003; Sandström \& Bergström, 2005) and increase civic skills such as voter activity, 
volunteering, charitable activity, and tolerance of others (Campbell, 2002; Bettinger \& Slonim, 2006; Fleming, 2014; Fleming, Mitchell, \& McNally, 2014).

Though many studies have examined whether private schools outperform public schools, few have looked at why there are differences in short and long-term student outcomes. Wolf and Hoople (2006) attempted to peer into the black box of the school choice reform through examination of the DC Opportunity Scholarship Program and found that the successful private schools allocated fewer resources to facilities and programs. Our study fits into the literature by examining a potential explanation for why school choice could have an advantage in producing slightly positive outcomes for students.

We examine the differences in the autonomy of school leaders, which may increase the likelihood that leaders can adapt to the changing needs of students and staff within their schools. Effective leadership, and an environment to support the ability to make effective decisions within a school, may be important for creating a high-quality educational experience for children (Rousmaniere, 2013). For example, Grissom, Loeb and Master (2013) find that principals that can spend time on things such as the school's education curriculum can positively influence student achievement. Conversely, they find that principals that spend more time on activities such as simple classroom walkthroughs may have a negative impact on student growth. Additionally, Ouchi (2009) and Hess (2013) point out that student learning cannot be improved unless school leaders have control over important school-level activities such as curriculum and the budget.

In schooling, leaders that are free to influence important decisions may be better able to change their approach to curriculum, instruction, or professional development practices if their leaders notice inefficiencies (Tekleselassie \& Villarreal III, 2011). However, schools with 
constrained leadership will be less likely to capitalize on the benefits associated with needed reform strategies. Branch, Hanushek and Rivkin (2013) point out that highly effective principals increase student learning by two to seven months within a single school year. Chubb and Moe (1988, p. 1065) found that the public and private schools were "distinctively different in environment and organization" and that private school principals had more teaching experience than public school principals. They also theorized that greater autonomy would exist in private schools with respect to their structure, goals and school operations. However, Chubb and Moe did not empirically test this specific theory.

We provide the first study to empirically test the hypothesis that the private schooling sector allows for more leadership autonomy by using nationally representative survey data of principals in the United States for the 2011-12 school year from the School and Staffing Survey. We compare the reported differences between public and private school principals' influence on decision-making activities within their schools. Since we simply want to make overall comparisons between the two types of institutions, we do not examine subcategories of private schools and public schools.

\section{Theory}

In private schools, families have lower transaction costs associated with opting to leave the school, making the school operators more prone to the threat of a shutdown condition (Friedman, 1955; West, 1981). However, loss for a private school is not only monetary in the short-run; it can also cause several chain reactions such as damaged brand name, threat to teachers' jobs, and threat of change in the perception of future clients. Since families are more able to leave the private school if they are dissatisfied, it is more necessary for the school leader to be able to make changes to influence customer satisfaction levels (Smith, 1776; West, 1997). 
If a private school principal is able to make the decisions necessary to adapt to the signals transmitted by his or her clients, the quality of their schooling should increase. Since the public school often has a monopoly on public funding, and their customers are assigned residentially, their leaders do not need to adapt to dissatisfaction as quickly (Hoxby, 2007; Peterson, 1998; Peterson \& Hassel, 1998). In other words, the transaction costs for a customer leaving a public school are much higher, especially since it would require Tiebout choice (Tiebout, 1956) or paying for a private school out of pocket (Friedman \& Friedman, 1990; Merrifield, 2008). In fact, since the transaction costs are typically much higher in order to exit a public school, large amounts of principal autonomy may not be desirable in that sector (Neal, 2002). If a malicious, or simply ineffective, principal becomes the leader of the school, we may not want them making school-level decisions that could negatively affect students (Hayek, 2011). If the ineffective principal is free to make bad decisions, many students may be harmed without much of an exit option, especially if they come from a disadvantaged family (Gaventa, 1982; Lerner, 1995). Since this scenario is potentially more likely and costly in public institutions, the public sector may be more likely to be set up in a way to limit the possibility of this negative event occurring. As a result, an official from the central office may be more likely to control the important school-level decisions.

The private school principal is likely to have more influence in decision-making since the private schools have fewer political constraints and enjoy more autonomy in selection of students and daily administration than public schools (Firestone \& Shipps, 2005; Shipps \& White, 2009; White, 2006). Since private school principal are at least less likely to feel the pressures of political constraints, they may feel more confident and able to influence school-level activities. Private school leaders may be more likely to establish an environment of similar students 
working towards a uniform mission through selective-admissions and an improved match between school goals and student interests.

Additionally, private school principals may face a stronger dismissal threat than their public school counterparts. If school leaders have fewer costs associated with dismissing their principals, they will be more likely to be able to hold them accountable for their actions. If a private school principal can be dismissed easily, they will have a stronger incentive to make effective decisions. On the other hand, if a school principal is protected through unionization or otherwise, they will be more likely to make ineffective decisions without the same level of accountability (Chubb \& Moe, 1986; Painter, 2000; Tucker, 1997; Weisburg et al., 2009). Since it is more difficult to fire a principal in the public sector, we expect that a centralized official will reduce their autonomy in order to limit negative outcomes for students. Furthermore, since school principals in the public sector are more likely to have an incentive to maximize budgets, we expect that central offices will not grant them much autonomy over finance decisions (Niskanen, 1971).

\section{Data}

The data for the public and private school principals comes from the School and Staffing Survey (SASS) 2011-2012 questionnaire. SASS was developed by the National Center for Education Statistics (NCES) and it has been administered seven times since 1987-88 to 20112012. Table 1 lists the question categories and what they measure ${ }^{1}$. The public school principal data file contained 7,510 records while the private school principal data file contained 1,720

\footnotetext{
${ }^{1}$ For more information, see http://nces.ed.gov/surveys/sass/pdf/1112/SASS2A.pdf (for public school principals) and http://nces.ed.gov/surveys/sass/pdf/1112/SASS2B.pdf (for private school principals).
} 
records. There were some additional questions for public school principals, but in this paper, we compare only the common questions related to decision making.

Our dependent variables come from questions 16-A through $16-\mathrm{G}$ on decision-making in SASS 2011-2012. These variables measure the influence principals perceive to have on setting performance standards, establishing curriculum, determining content for professional development, evaluating teachers, hiring teachers, setting discipline policy, and deciding how the budget will be spent. This section asks the principals to rate their ability to influence seven school related activities on a four-item Likert scale (no influence, minor influence, moderate influence and major influence) and it includes a not applicable option for each activity (Table 1).

[Table 1 about here]

We utilize questions from the survey that relate to principal's demographics, academic and professional background for summary statistics. Tables $2 \mathrm{~A}$ and $2 \mathrm{~B}$ show the population weighted summary statistics expressed as percentages for the principals in public and private schools. Overall, private school principals report more years of principal experience but lower education levels in comparison to the public school principals. This is consistent with the findings of Hill et al. (2016). The proportion of private school principals reporting greater than 10 years of experience as a principal or school head is almost double that of public school principals. The proportion of private school principals involved in teaching in addition to their task as a principal or school head is also about twice that for public school principals.

A higher proportion of public school principals report having previous experience as a department head, assistant principal or program director and participation in a school training or development program in comparison to their private counterparts. The proportion of public school principals holding a school administration license is about twice as large as private school 
principals. Almost all public school principals earned a MA or higher degree while only $76 \%$ of the private school principals report so. The racial composition of principals is largely white in both the sectors ( $86 \%$ in public schools and $90 \%$ in private schools; this excludes mixed race, so it is a lower bound). Lastly, private schools have a larger share of females in their leadership in comparison to the public schools.

[Table 2A about here]

[Table 2B about here]

We also report summary statistics on the percent of private and public school principals to report having a major influence on of the seven outcome categories in Table 3.

[Table 3 about here]

\section{Methods}

Since the survey responses related to decision-making are ordinal and have four categories (from "No Influence" to "Major Influence"), the analytic technique we employ is an ordered logistic regression (Borooah, 2002; Cohen, Cohen, West, \& Aiken, 2003) of the form:

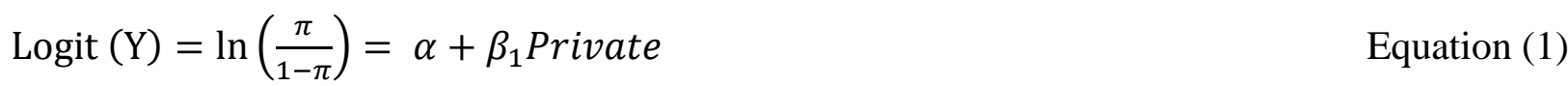
Therefore:

$\pi=$ Probability $(Y=$ Major Influence, given Private $=$ private $)$ Equation (2)

$$
\pi=\frac{e^{\alpha+\beta_{1} \text { Private }}}{1+e^{\alpha+\beta_{1} \text { Private }}}
$$

The dependent variable of interest is the reported decision-making ability of a given principal, $i$, for the following school-level activities: setting student performance standards, establishing curriculum, determining teacher professional development content, evaluating teachers, hiring new full-time teachers, setting discipline policy and deciding how the budget will be spent. This variable takes the value 1 for the least influence and value 4 for the highest 
influence. ${ }^{2}$ Private is a dummy variable of value 1 if the principal is in a private school, and 0 if the principal is in a public school. The coefficient of interest, $\beta_{1}$, measures the mean difference of the decision-making influence reported by private school principals relative to public school principals. The odds ratio, $\pi$, is the likelihood for private school principals, relative to public school principals, to report having a major influence on a given school-level activity.

Since we want to examine the differences between principals based solely on the type of institution they are in, this initial model does not control for any principal or school-level differences. In order to construct a conservative estimate of the association between institutiontype and decision-making freedom, we construct the following model that also includes school and principal characteristics as controls:

$$
\operatorname{Logit}(\mathrm{Y})=\ln \left(\frac{\pi}{1-\pi}\right)=\alpha+\beta_{1} \text { Private }+\beta_{2} X
$$

Therefore:

$$
\begin{gathered}
\pi=\text { Probability }(Y=\text { Major Influence, given Private }=\text { private, } X=x) \quad \text { Equation (2) } \\
\pi=\frac{e^{\alpha+\beta 1 \text { Private }+\beta 2 \mathrm{X}}}{1+e^{\alpha+\beta 1 \text { Private }+\beta 2 \mathrm{X}}}
\end{gathered}
$$

$X$ is a vector of controls which includes the following principal characteristics: race, gender, education level, years of experience as a principal or school head, years of experience as a teacher in elementary or secondary school, any experience as a department head, any experience as an assistant principal, participation in professional development or training programs, management experience outside of education, and whether the principle holds a license in school administration. Vector $\mathrm{X}$ also includes these school-level characteristics: school size, school level, number of full-time teachers, student/teacher ratio, percent of minority

\footnotetext{
${ }^{2}$ Since the dependent variable is ordinal, we use ordered logit regression and report average marginal effects for the likelihood of reporting "major influence."
} 
teachers, and percent of minority students. This second model includes school and principal level controls in order to examine if the effects are significant after accounting for differences in the types of schools and principals hired across the two institutions.

The restricted use data provided by the NCES are imputed and adjusted for non-response. Based on the stratified probability proportionate to size (PPS) sampling strategy used by NCES in the SASS, we use the balance repeated replication (BRR) bootstrap methodology ${ }^{3}$ so that the results reflect the true population values and not just the sampled units. This methodology does not change our final estimates, but rather corrects the formula for the calculation of the standard errors.

\section{Results}

We now present the results for our models with and without controls in Table 4. The first row presents results without any controls, the second includes principal-level controls, and the third includes all school and principal-level controls. The results are robust across models; however, the model without controls only finds statistical significance for the first four categories.

The model with all controls indicates that private school principals are more likely to report having a major influence on 6 out of 7 types of school decisions. When controlling for school and principal-level differences across sectors, we find evidence that private school principals exercise significantly more influence over decision-making activities. In particular, private school principals have a higher likelihood of reporting to have a major influence over performance standards, curriculum, professional development, hiring teachers, discipline policy, and budget decisions. However, private schools principals have a 3.9 percentage point, or 4.1

\footnotetext{
${ }^{3}$ Details can be found in the User's Manual for the 2011-12 Schools and Staffing Survey: https://nces.ed.gov/surveys/sass/methods0708.asp
} 
percent, lower likelihood of reporting to have a major influence on the evaluation of teachers.

Since private school principals have a 4.9-percentage point higher likelihood of having a major influence over the hiring of teachers, they may not need to provide as much direct feedback. In addition, since private school principals have a 14.4-percentage point, or 20.7 percent, higher likelihood of having a major influence on the content of their teacher professional development programs, they may provide feedback through that channel instead. Notably, private school principals have a 20 -percentage point, or 47 percent, higher likelihood of reporting that they have a major influence on establishing their school's curriculum. Furthermore, private school principals have a 14-percentage point, or 19 percent, higher likelihood of reporting that they have a major influence on their students' performance standards. This may be especially important for the ability of the principal to positively impact student achievement.

\section{[Table 4 about here]}

Based on our results, we expect that the reduced regulatory burden found in private schools grants the principals the ability to exercise more influence related to school activities in comparison to public school principals. To explore our analysis further, we examine the coefficients on the control variables for our preferred model, found in Table 5.

[Table 5 about here]

Most of our school-level controls are unrelated to the seven outcome measures of interest; however, some statistical significance emerges. Principals within larger schools are more likely to report having a major influence on performance standards, but less likely to report so for establishing curriculum. Principals in secondary schools are more likely to report having a major influence in performance standards and curriculum, but less likely to report having influence over discipline and budget decisions. Being in a school with a more diverse set of 
teachers is associated with a higher likelihood of reporting a major influence on performance standards and curriculum.

The coefficient on the principal's previous experience as a department head is significant and positive in all cases except for the case of teacher evaluation, where it is not statistically different from zero. Hence, previous leadership experience has a systematic positive relationship with the principal's ability to influence school level activities. Lower levels of previous principal experience and previous teaching experience are associated with a lower likelihood of reporting to have an influence on most categories.

Having a master's or higher degree appears to be a positive principal characteristic. It could be that education itself improves decision-making ability or that people that choose to pursue more education are also more motivated and confident. The coefficient on female is positive throughout and statistically significant for three of the seven activities. Females seem to have systematic advantages over males in their influence over school-related activities, even after controlling for background and types of school. Since about three-fourths of all elementary and secondary-level teachers are female, female principals may be more able to have a strong connection with their employees (Goldring et al., 2013). Minority principals have a lower likelihood of reporting that they have an influence over hiring teachers and setting discipline policy, but a higher likelihood of reporting that they have an influence over student performance standards and curriculum.

\section{Conclusion and Policy Implications}

The principals in both sectors differ significantly in decision-making abilities when it comes to their influence on school-level activities. The private school principals may have an advantage over their public school counterparts by having significantly more influence on almost 
all the school related activities. Principal characteristics, like previous experience as a department head and having a Masters or higher degree, play a positive role in their ability to exercise higher influence on school activities. Nevertheless, the private school sector may be able to learn from the public school sector in evaluating teachers. Female principals appear to have a systematic advantage over their male counterparts in reporting more decision-making influence related to school activities.

In terms of policy implications, private school principals report to have more autonomy than public school principals on every aspect of decision-making ability except the evaluation of teachers. These findings may point towards the need of training in evaluation activities for the private sector. However, it could mean that the private school sector has a lower need for direct teacher feedback since they have more autonomy in hiring decisions and more involvement in the schools, as Chubb and Moe (1988) find. If principal autonomy is associated with enhanced educational experiences for children, and the private sector allows for more decision-making freedom, we should increase access to private school choice. However, these policy decisions would benefit substantially from additional research linking principal autonomy to student-level outcomes.

Our results may also reflect the emphasis that recent Race to the Top related policy changes have imposed on traditional public schools (Maranto et al., 2016). Ouchi (2009) has emphasized the importance of principal autonomy and argued that principals know what happens at the school-level while central office employees do not. Perhaps, the relatively short tenure but greater credentialing of public school principals, as well as larger school size may suggest that they are climbers; that is, they see the principal position as a stepping-stone to the superintendence and focus on pleasing superiors rather than serving kids (Downs, 1967; Maranto 
et al., 2016). Cheng (2015) finds that schools where principals have more autonomy over personnel have greater mission coherence, though his sample only includes public schools.

Since we have relied on self-reported measures in school surveys, the results are prone to social desirability bias as well as reference group bias (Dobbie \& Fryer, 2015; West et al., 2015). Although SASS is a nationally representative sample and stable results over time can have good external validity, future studies should utilize other measures like value-added measures related to school's graduation rates and teacher turnover to study principal's leadership qualities. 


\section{References}

Abdulkadiroglu, A., Pathak, P. A., \& Walters, C. R. (2015). School Vouchers and Student Achievement: Evidence from the Louisiana Scholarship Program (No. w21839). National Bureau of Economic Research.

Betts, J. R., \& Tang, Y. E. (2011). The Effect of Charter Schools on Student Achievement: A Meta-Analysis of the Literature. Center on Reinventing Public Education.

Booker, K., Sass, T. R., Gill, B., \& Zimmer, R. (2008). Going Beyond Test Scores: Evaluating Charter School Impact on Educational Attainment in Chicago and Florida. Working Paper WR-610-BMG, Rand Education, Santa Monica, CA.

Borooah, V. K. (2002). Logit and Probit: Ordered and Multinomial Models (No. 138). Sage.

Branch, G. F., Hanushek, E. A., \& Rivkin, S. G. (2013). School Leaders Matter. Education Next, 13(1).

Campbell, D. E. (2002). The Civic Side of School Reform: How Do School Vouchers Affect Civic Education?. Center for the Study of Democratic Politics Working Paper.

Cheng, A. (2015). Do Personnel Policies Matter for Organizational Mission Coherence? A Public School Test. Review of Public Personnel Administration. doi:10.1177/0734371X15587981.

Chubb, J. E., \& Moe, T. M. (1986). No School is an Island: Politics, Markets, and Education. The Brookings Review, 4(4), 21-28.

Chubb, J. E., \& Moe, T. M. (1988). Politics, Markets, and the Organization of Schools. American Political Science Review, 82(04), 1065-1087.

Cohen, J., Cohen, P., West, S. G., \& Aiken, L. S. (2003). Applied Multiple Correlation/Regression Analysis for the Behavioral Sciences. UK: Taylor \& Francis. 
Cowen, J. M., Fleming, D. J., Witte, J. F., Wolf, P. J., \& Kisida, B. (2013). School Vouchers and Student Attainment: Evidence from a State-Mandated Study of Milwaukee's Parental Choice Program. Policy Studies Journal, 41(1), 147-168.

DeAngelis, C., \& Wolf, P. J. (2016). The School Choice Voucher: A Get Out of Jail Card? EDRE Working Paper 2016-03. Available at SSRN: https://ssrn.com/abstract=2743541

Deming, D. J. (2011). Better Schools, Less Crime?. The Quarterly Journal of Economics, 126, 2063-2115.

Dobbie, W., \& Fryer, R.G. (2015). The Medium-Term Impacts of High-Achieving Charter Schools. Journal of Political Economy, 123(5), 985-1037.

Downs, A. (1967). Inside Bureaucracy. Boston: Little, Brown.

Egalite, A. J. (2013). Measuring Competitive Effects from School Voucher Programs: A Systematic Review. Journal of School Choice, 7(4), 443-464.

Egalite, A. J. (2016). The Competitive Effects of the Louisiana Scholarship Program on Public School Performance. Available at SSRN 2739783.

Figlio, D., \& Hart, C. (2014). Competitive Effects of Means-Tested School Vouchers. American Economic Journal: Applied Economics, 6(1), 133-156.

Firestone, W. A., \& Shipps, D. (2005). How Do Leaders Interpret Conflicting Accountabilities to Improve Student Learning. A New Agenda for Research in Educational Leadership, 81100.

Fleming, D. J. (2014). Learning from Schools: School Choice, Political Learning, and Policy Feedback. Policy Studies Journal, 42(1), 55-78. 
Fleming, D. J., Mitchell, W., \& McNally, M. (2014). Can Markets Make Citizens? School Vouchers, Political Tolerance, and Civic Engagement. Journal of School Choice, 8(2), 213-236.

Forster, G. (2016). A Win-Win Solution: The Empirical Evidence on School Choice. Indianapolis: Friedman Foundation for Educational Choice.

Friedman, M. (1955). The Role of Government in Education. Rutgers University Press.

Friedman, M., \& Friedman, R. (1990). Free to Choose: A Personal Statement. Houghton Mifflin Harcourt.

Gaventa, J. (1982). Power and Powerlessness: Quiescence and Rebellion in an Appalachian Valley. University of Illinois Press.

Goldring, R., Gray, L., \& Bitterman, A. (2013). Characteristics of Public and Private Elementary and Secondary School Teachers in the United States: Results from the 201112 Schools and Staffing Survey (NCES 2013-314). Washington, DC: National Center for Education Statistics.

Greene, J. P. (2005). Education Myths: What Special Interest Groups Want You To Believe About Our Schools--And Why It Isn't So. Rowman \& Littlefield Publishers.

Greene, J. P., \& Winters, M. A. (2003). When Schools Compete: The Effects of Vouchers on Florida Public School Achievement. New York, NY: Center for Civic Innovation, Manhattan Institute.

Grissom, J. A., Loeb, S., \& Master, B. (2013). Effective Instructional Time Use for School Leaders: Longitudinal Evidence from Observations of Principals. Educational Researcher, 42(8), 433-444. 
Hayek, F. A. (2011). The Fatal Conceit: The Errors of Socialism (Vol. 1). University of Chicago Press.

Hess, F. M. (2013). Cage-Busting Leadership. Cambridge, MA: Harvard Education Press.

Hill, J., Ottem, R., DeRoche, J., \& Owens, C. (2016). Trends in Public and Private School Principal Demographics and Qualifications: 1987-88 to 2011-12. National Center for Education Statistics.

Hoxby, C. M. (Ed.). (2007). The Economics of School Choice. University of Chicago Press. Lerner, A. (1995). The Concept of Monopoly and the Measurement of Monopoly Power. In Essential Readings in Economics (pp. 55-76). Macmillan Education UK.

Maranto, R., Teodoro, M., Cheng, A., \& Carroll, K. (2016). Gender, Career Paths \& Bureaucratic Ambition.

Maranto, R., McShane, M. Q. \& Rhinesmith, E. (2016). Education Reform in the Obama Era: The Second Term and the 2016 Election. New York: Palgrave/Macmillan Pivot.

Merrifield, J. (2008). The Twelve Policy Approaches to Increased School Choice. Journal of School Choice, 2(1), 4-19.

Mills, J. N., \& Wolf, P. J. (2016). The Effects of the Louisiana Scholarship Program on Student Achievement after Two Years. Available at SSRN 2738805.

Neal, D. (2002). How Vouchers Could Change The Market For Education. The Journal of Economic Perspectives, 16(4), 25-44.

Niskanen, W. A. (1971). Bureaucracy and Representative Government. Transaction Publishers.

Ouchi, W. G. (2009). The Secret of TSL: The Revolutionary Discovery That Raises School Performance. New York: Simon and Schuster. 
Painter, S. R. (2000). Principals' Perceptions of Barriers to Teacher Dismissal. Journal of Personnel Evaluation in Education, 14(3), 253-264.

Peterson, P. E. (1998). School Choice: A Report Card. Virginia Journal of Social Policy \& the Law, 6, 47.

Peterson, P. E., \& Hassel, B. C. (Eds.). (1998). Learning from School Choice. Brookings Institution Press.

Rousmaniere, K. (2013). The Principal's Office: A Social History of the American School Principal. SUNY Press.

Sandström, F. M., \& Bergström, F. (2005). School Vouchers in Practice: Competition Will Not Hurt You. Journal of Public Economics, 89(2), 351-380.

Shakeel, M., Anderson, K. P., \& Wolf, P. J. (2016). The Participant Effects of Private School Vouchers Across the Globe: A Meta-Analytic and Systematic Review. EDRE Working Paper No. 2016-07. Available at SSRN: https://ssrn.com/abstract=2777633

Shipps, D., \& White, M. (2009). A New Politics of the Principalship? Accountability-Driven Change in New York City. Peabody Journal of Education, 84(3), 350-373.

Smith, A. (1776). An Inquiry into the Wealth of Nations. Strahan and Cadell, London.

Tekleselassie, A. A., \& Villarreal III, P. (2011). Career Mobility and Departure Intentions among School Principals in the United States: Incentives and Disincentives. Leadership and Policy in Schools, 10(3), 251-293.

Tiebout, C. M. (1956). A Pure Theory of Local Expenditures. The journal of political economy, 416-424.

Tooley, J. (2005). Reclaiming Education. Bloomsbury Publishing. 
Tooley, J., Bao, Y., Dixon, P., \& Merrifield, J. (2011). School Choice and Academic Performance: Some Evidence from Developing Countries. Journal of School Choice, $5(1), 1-39$.

Tucker, P. D. (1997). Lake Wobegon: Where All Teachers Are Competent (Or, Have We Come to Terms with the Problem of Incompetent Teachers?). Journal of Personnel Evaluation in Education, 11(2), 103-126.

Weisberg, D., Sexton, S., Mulhern, J., Keeling, D., Schunck, J., Palcisco, A., \& Morgan, K. (2009). The widget effect: Our National Failure to Acknowledge and Act on Differences in Teacher Effectiveness. New Teacher Project.

West, E. G. (1981). Choice or Monopoly in Education. Policy Review, (15), 103.

West, E. G. (1997). Education Vouchers in Principle and Practice: a Survey. The World Bank Research Observer, 12(1), 83-103.

West, M. R., \& Woessmann, L. (2010). ‘Every Catholic Child in a Catholic School’: Historical Resistance to State Schooling, Contemporary Private Competition and Student Achievement across Countries. The Economic Journal, 120(546), F229-F255.

West, M. R., Kraft, M. A., Finn, A. S., Martin, R. E., Duckworth, A. L., Gabrieli, C. F., \& Gabrieli, J. D. (2015). Promise and Paradox-Measuring Students' Non-Cognitive Skills and the Impact of Schooling. Educational Evaluation and Policy Analysis, 0162373715597298 .

White, M. A. (2006). A Case of New York City High School Principals' Experiences with Multiple Accountability Pressures and Accompanying Models for Decision-Making. Columbia University Teacher's College. 
Witte, J. F. (2001). The Market Approach to Education: An Analysis of America's First Voucher Program. Princeton: Princeton University Press.

Witte, J. F., Wolf, P. J., Cowen, J. M., Fleming, D. J., \& Lucas-McLean, J. (2008). MPCP longitudinal educational growth study: Baseline report. University of Arkansas Education Working Paper Archive.

Witte, J. F., Wolf, P. J., Cowen, J. M., Carlson, D., \& Fleming, D. F. (2014). High Stakes Choice: Achievement and Accountability in the Nation's Oldest Urban Voucher Program. Education Evaluation and Policy Analysis, 36(4), 437-456.

Wolf, P., Kisida, B., Gutmann, B., Puma, M., Eissa, N., \& Rizzo, L. (2013). School Vouchers and Student Outcomes: Experimental Evidence from Washington, DC. Journal of Policy Analysis and Management, 246-270.

Zimmer, R. (2009). Charter Schools in Eight States: Effects on Achievement, Attainment, Integration, and Competition. Santa Monica, CA: RAND Corporation. 
Table 1: School-Related Activities over Which the Principal Has Influence

\begin{tabular}{ll}
\hline Category & School-related activities \\
\hline A & Setting performance standards for students of this school \\
B & Establishing curriculum at this school \\
C & Determining the content of in-service professional development programs for \\
& teachers of this school \\
D & Evaluating teachers of this school \\
E & Hiring new full-time teachers of this school \\
F & Setting discipline policy at this school \\
$\mathrm{G}$ & Deciding how your school budget will be spent \\
\hline
\end{tabular}




\section{Table 2A: Summary Statistics for Principal Characteristics}

\begin{tabular}{lrr}
\hline \multicolumn{1}{c}{ Measure } & Public & Private \\
\hline Years principal or school head at this or any school prior to this year & 8.32 & 8.78 \\
no experience & 24.55 & 18.82 \\
low experience 1-3 & 43.79 & 30.97 \\
medium experience 4-10 & 23.34 & 41.43 \\
high experience 10+ & 16.46 & 14.52 \\
Years principal or school head at this school prior to this year & 38.83 & 27.62 \\
no experience & 36.07 & 32.92 \\
low experience 1-3 & 8.64 & 24.94 \\
medium experience 4-10 & 1.70 & 18.51 \\
high experience 10+ & 2.79 & 7.99 \\
Years of elementary or secondary teaching before becoming principal or school head & 47.34 & 32.79 \\
no experience & 48.16 & 40.71 \\
low experience 1-3 & & \\
medium experience 4-10 & 90.41 & 49.69 \\
high experience 10+ & 5.42 & 21.87 \\
Years of elementary or secondary teaching since becoming principal or school head & 3.30 & 15.87 \\
no experience & 0.87 & 12.56 \\
low experience 1-3 & 37.37 & 71.89 \\
medium experience 4-10 & \\
high experience 10+ & & \\
Currently teaching at school & & \\
\hline Notes: Summary statistics presented using population weighted percentages for each italicized category
\end{tabular}


Table 2B: Summary Statistics for Principal Characteristics

\begin{tabular}{lcc}
\hline \multicolumn{1}{c}{ Measure } & Public & Private \\
\hline Prior to becoming a principal of school head & & \\
$\quad$ Worked as department head & 40.36 & 35.33 \\
$\quad$ Worked as an assistant principal or program director & 73.85 & 43.82 \\
$\quad$ Participated in school training or development program & 55.34 & 31.41 \\
$\quad$ Previous management experience outside education & 40.28 & 46.43 \\
Currently holding license in school administration & 95.99 & 43.36 \\
Having a bachelor's degree & 99.94 & 88.47 \\
Bachelor degree awarded by a university's department or college of education & 81.93 & 67.78 \\
Having a master's degree & 97.61 & 76.34 \\
Master's degree awarded by a university's department or college of education & 97.36 & 85.38 \\
Earned a MA and higher degree & 97.82 & 68.96 \\
Participated in any professional development activity related to principal or school head in last 12 months & 99.32 & 89.56 \\
Race (white) & 86.36 & 90.19 \\
Gender (male) & 48.38 & 44.64 \\
$\mathrm{~N}$ & 7,510 & 1,720 \\
\hline
\end{tabular}

Notes: Summary statistics presented using population weighted percentages for each category. 
Table 3: Summary Statistics for Principals' Self-Reported Major Influence on Outcome Variables

\begin{tabular}{lcc}
\hline Measure & Public & Private \\
\hline Performance Standards & 73.32 & 80.37 \\
Establishing Curriculum & 42.63 & 69.07 \\
Professional Development & 69.49 & 74.21 \\
Teacher Evaluation & 95.34 & 82.01 \\
Hiring Teachers & 84.33 & 83.73 \\
Discipline Policy & 79.40 & 81.54 \\
Budget Spending & 63.79 & 62.06 \\
$\mathrm{~N}$ & 7,510 & 1,720 \\
\hline
\end{tabular}

Notes: Summary statistics presented using population weighted percentages for each category.

Table 4: Results Based on Model Used

\begin{tabular}{|c|c|c|c|c|c|c|c|}
\hline & $\begin{array}{c}\text { Performance } \\
\text { Standards }\end{array}$ & $\begin{array}{l}\text { Establishing } \\
\text { Curriculum }\end{array}$ & $\begin{array}{c}\text { Professional } \\
\text { Development }\end{array}$ & $\begin{array}{c}\text { Teacher } \\
\text { Evaluation }\end{array}$ & $\begin{array}{c}\text { Hiring } \\
\text { Teachers }\end{array}$ & $\begin{array}{c}\text { Discipline } \\
\text { Policy }\end{array}$ & $\begin{array}{c}\text { Budget } \\
\text { Spending }\end{array}$ \\
\hline No Controls & $\begin{array}{c}\mathbf{0 . 0 7 2} * * * \\
(0.018)\end{array}$ & $\begin{array}{c}\mathbf{0 . 2 4 7} * * * \\
(0.017)\end{array}$ & $\begin{array}{c}\mathbf{0 . 1 2 6}^{* * * *} \\
(0.019)\end{array}$ & $\begin{array}{c}\mathbf{- 0 . 0 6 4} * * * * \\
(0.009)\end{array}$ & $\begin{array}{c}\mathbf{0 . 0 1 9} \\
(0.014)\end{array}$ & $\begin{array}{c}\mathbf{0 . 0 1 8} \\
(0.014)\end{array}$ & $\begin{array}{c}\mathbf{0 . 0 0 1} \\
(0.017)\end{array}$ \\
\hline Principal Controls & $\begin{array}{c}\mathbf{0 . 1 4 6}^{* * * *} \\
(0.017)\end{array}$ & $\begin{array}{c}\mathbf{0 . 2 5 9} * * * \\
(0.018)\end{array}$ & $\begin{array}{c}\mathbf{0 . 1 4 1} * * * \\
(0.017)\end{array}$ & $\begin{array}{c}\mathbf{- 0 . 0 3 4} * * * \\
(0.009)\end{array}$ & $\begin{array}{c}\mathbf{0 . 0 5 0}^{* * * *} \\
(0.014)\end{array}$ & $\begin{array}{c}\mathbf{0 . 0 6 0}^{* * * *} \\
(0.017)\end{array}$ & $\begin{array}{c}\mathbf{0 . 0 4 9} * * \\
(0.021)\end{array}$ \\
\hline Principal and School Controls & $\begin{array}{c}\mathbf{0 . 1 4 0 * * *} \\
(0.018)\end{array}$ & $\begin{array}{c}\mathbf{0 . 2 0 0} * * * * \\
(0.019)\end{array}$ & $\begin{array}{c}\mathbf{0 . 1 4 4} * * * \\
(0.016)\end{array}$ & $\begin{array}{c}-\mathbf{- 0 . 0 3 9} * * * * \\
(0.009)\end{array}$ & $\begin{array}{c}\mathbf{0 . 0 4 9} * * * * \\
(0.014)\end{array}$ & $\begin{array}{c}\mathbf{0 . 0 6 7 * * * *} \\
(0.017)\end{array}$ & $\begin{array}{c}\mathbf{0 . 0 7 1} * * * \\
(0.021)\end{array}$ \\
\hline Observations & 9,230 & 9,230 & 9,230 & 9,230 & 9,230 & 9,230 & 9,230 \\
\hline
\end{tabular}


Table 5: Likelihood of Reporting Major Influence (All Controls)

\begin{tabular}{|c|c|c|c|c|c|c|c|}
\hline & $\begin{array}{c}\text { Performance } \\
\text { Standards }\end{array}$ & $\begin{array}{l}\text { Establishing } \\
\text { Curriculum }\end{array}$ & $\begin{array}{l}\text { Professional } \\
\text { Development }\end{array}$ & $\begin{array}{c}\text { Teacher } \\
\text { Evaluation }\end{array}$ & $\begin{array}{c}\text { Hiring } \\
\text { Teachers }\end{array}$ & $\begin{array}{l}\text { Discipline } \\
\text { Policy }\end{array}$ & $\begin{array}{c}\text { Budget } \\
\text { Spending }\end{array}$ \\
\hline Private School Principal & $\begin{array}{c}0.140 * * * \\
(0.018)\end{array}$ & $\begin{array}{c}0.200 * * * \\
(0.019)\end{array}$ & $\begin{array}{c}0.144 * * * \\
(0.016)\end{array}$ & $\begin{array}{c}-0.039 * * * \\
(0.009)\end{array}$ & $\begin{array}{c}0.049 * * * \\
(0.014)\end{array}$ & $\begin{array}{c}0.067 * * * \\
(0.017)\end{array}$ & $\begin{array}{c}0.071 * * * \\
(0.021)\end{array}$ \\
\hline School Size & $\begin{array}{l}0.009^{*} \\
(0.005)\end{array}$ & $\begin{array}{l}-0.011 * \\
(0.006)\end{array}$ & $\begin{array}{c}0.009 \\
(0.007)\end{array}$ & $\begin{array}{c}0.000 \\
(0.003)\end{array}$ & $\begin{array}{c}0.004 \\
(0.004)\end{array}$ & $\begin{array}{c}0.007 \\
(0.006)\end{array}$ & $\begin{array}{l}-0.006 \\
(0.008)\end{array}$ \\
\hline School Level & $\begin{array}{l}0.018^{*} \\
(0.010)\end{array}$ & $\begin{array}{c}0.073 * * * \\
(0.008)\end{array}$ & $\begin{array}{c}0.017 \\
(0.011)\end{array}$ & $\begin{array}{l}-0.003 \\
(0.004)\end{array}$ & $\begin{array}{l}-0.001 \\
(0.006)\end{array}$ & $\begin{array}{c}-0.017 * * \\
(0.008)\end{array}$ & $\begin{array}{c}-0.044 * * * \\
(0.010)\end{array}$ \\
\hline Number of Full Time Teachers & $\begin{array}{l}-0.000 \\
(0.001)\end{array}$ & $\begin{array}{c}-0.001 * * \\
(0.001)\end{array}$ & $\begin{array}{l}-0.001 * \\
(0.001)\end{array}$ & $\begin{array}{l}-0.000 \\
(0.000)\end{array}$ & $\begin{array}{c}0.001 \\
(0.001)\end{array}$ & $\begin{array}{l}-0.000 \\
(0.001)\end{array}$ & $\begin{array}{c}0.001 \\
(0.001)\end{array}$ \\
\hline Student/Teacher Ratio & $\begin{array}{l}-0.001 \\
(0.002)\end{array}$ & $\begin{array}{l}-0.002 * \\
(0.001)\end{array}$ & $\begin{array}{l}-0.001 \\
(0.002)\end{array}$ & $\begin{array}{l}-0.000 \\
(0.001)\end{array}$ & $\begin{array}{l}-0.001 \\
(0.002)\end{array}$ & $\begin{array}{l}-0.001 \\
(0.002)\end{array}$ & $\begin{array}{l}-0.000 \\
(0.003)\end{array}$ \\
\hline Teacher Diversity & $\begin{array}{c}0.001 * * * \\
(0.000)\end{array}$ & $\begin{array}{c}0.001 * * * \\
(0.000)\end{array}$ & $\begin{array}{c}0.000 \\
(0.000)\end{array}$ & $\begin{array}{c}0.000 \\
(0.000)\end{array}$ & $\begin{array}{l}-0.000 \\
(0.000)\end{array}$ & $\begin{array}{l}-0.000 \\
(0.000)\end{array}$ & $\begin{array}{c}0.000 \\
(0.000)\end{array}$ \\
\hline Minority Students & $\begin{array}{l}-0.000 \\
(0.000)\end{array}$ & $\begin{array}{c}-0.001 * * \\
(0.000)\end{array}$ & $\begin{array}{l}-0.000 \\
(0.000)\end{array}$ & $\begin{array}{l}-0.000 \\
(0.000)\end{array}$ & $\begin{array}{c}-0.001^{* *} \\
(0.000)\end{array}$ & $\begin{array}{c}0.000 \\
(0.000)\end{array}$ & $\begin{array}{c}0.000 \\
(0.000)\end{array}$ \\
\hline Low principal Experience & $\begin{array}{c}-0.060 * * \\
(0.025)\end{array}$ & $\begin{array}{c}-0.053 * * \\
(0.023)\end{array}$ & $\begin{array}{c}0.037 \\
(0.029)\end{array}$ & $\begin{array}{l}-0.001 \\
(0.016)\end{array}$ & $\begin{array}{c}0.015 \\
(0.022)\end{array}$ & $\begin{array}{c}-0.085^{* * *} * \\
(0.026)\end{array}$ & $\begin{array}{c}-0.095 * * * \\
(0.023)\end{array}$ \\
\hline Low Teaching Experience & $\begin{array}{l}-0.042 \\
(0.035)\end{array}$ & $\begin{array}{l}-0.064 \\
(0.040)\end{array}$ & $\begin{array}{c}0.069 \\
(0.076)\end{array}$ & $\begin{array}{c}-0.034 * * \\
(0.016)\end{array}$ & $\begin{array}{l}-0.050 * \\
(0.029)\end{array}$ & $\begin{array}{l}-0.049 * \\
(0.029)\end{array}$ & $\begin{array}{c}0.028 \\
(0.043)\end{array}$ \\
\hline Department Head & $\begin{array}{c}0.034 * * * \\
(0.012)\end{array}$ & $\begin{array}{c}0.052 * * * \\
(0.012)\end{array}$ & $\begin{array}{c}0.039 * * * \\
(0.012)\end{array}$ & $\begin{array}{c}0.003 \\
(0.005)\end{array}$ & $\begin{array}{c}0.034 * * * \\
(0.011)\end{array}$ & $\begin{array}{c}0.024 * * \\
(0.012)\end{array}$ & $\begin{array}{c}0.041^{* * *} * \\
(0.015)\end{array}$ \\
\hline Assistant Principal/Program Director & $\begin{array}{l}-0.027^{*} \\
(0.015)\end{array}$ & $\begin{array}{c}-0.046^{* * * *} \\
(0.013)\end{array}$ & $\begin{array}{c}0.001 \\
(0.013)\end{array}$ & $\begin{array}{l}-0.004 \\
(0.006)\end{array}$ & $\begin{array}{c}0.007 \\
(0.013)\end{array}$ & $\begin{array}{l}-0.029 * \\
(0.015)\end{array}$ & $\begin{array}{c}0.032 * * \\
(0.013)\end{array}$ \\
\hline School Training/ Development & $\begin{array}{c}0.044 * * * \\
(0.013)\end{array}$ & $\begin{array}{c}0.015 \\
(0.013)\end{array}$ & $\begin{array}{l}0.018^{*} \\
(0.011)\end{array}$ & $\begin{array}{c}0.007 \\
(0.005)\end{array}$ & $\begin{array}{l}-0.006 \\
(0.009)\end{array}$ & $\begin{array}{c}0.015 \\
(0.010)\end{array}$ & $\begin{array}{c}0.016 \\
(0.012)\end{array}$ \\
\hline License in School Administration & $\begin{array}{c}0.045^{* *} \\
(0.022)\end{array}$ & $\begin{array}{c}0.032 \\
(0.023)\end{array}$ & $\begin{array}{c}0.022 \\
(0.023)\end{array}$ & $\begin{array}{c}0.031 * * * \\
(0.009)\end{array}$ & $\begin{array}{c}0.004 \\
(0.013)\end{array}$ & $\begin{array}{l}0.037 * \\
(0.020)\end{array}$ & $\begin{array}{c}0.019 \\
(0.031)\end{array}$ \\
\hline Management Experience & $\begin{array}{c}0.005 \\
(0.014)\end{array}$ & $\begin{array}{c}0.012 \\
(0.014)\end{array}$ & $\begin{array}{l}-0.023^{*} \\
(0.014)\end{array}$ & $\begin{array}{c}0.002 \\
(0.007)\end{array}$ & $\begin{array}{c}0.001 \\
(0.011)\end{array}$ & $\begin{array}{c}0.017 \\
(0.012)\end{array}$ & $\begin{array}{l}-0.006 \\
(0.014)\end{array}$ \\
\hline Master's Degree or Higher & $\begin{array}{c}0.062 * * \\
(0.030)\end{array}$ & $\begin{array}{l}-0.004 \\
(0.028)\end{array}$ & $\begin{array}{l}-0.024 \\
(0.047)\end{array}$ & $\begin{array}{c}0.007 \\
(0.011)\end{array}$ & $\begin{array}{l}0.035^{*} \\
(0.019)\end{array}$ & $\begin{array}{l}0.051^{*} \\
(0.027)\end{array}$ & $\begin{array}{c}0.075 * * \\
(0.033)\end{array}$ \\
\hline Professional Development & $0.146^{* * *}$ & $0.148 * * *$ & 0.034 & 0.019 & 0.059 & 0.054 & 0.076 \\
\hline
\end{tabular}


WHO IS MORE FREE? A COMPARISON OF THE DECISION-MAKING

\begin{tabular}{|c|c|c|c|c|c|c|c|}
\hline & $(0.046)$ & $(0.057)$ & $(0.126)$ & $(0.020)$ & $(0.056)$ & $(0.036)$ & $(0.062)$ \\
\hline \multirow[t]{2}{*}{ White } & -0.006 & $-0.041 *$ & 0.010 & 0.002 & $0.035^{* *}$ & $0.051 * * *$ & 0.020 \\
\hline & $(0.018)$ & $(0.023)$ & $(0.019)$ & (0.009) & $(0.015)$ & $(0.016)$ & $(0.021)$ \\
\hline \multirow[t]{2}{*}{ Female } & 0.022 & 0.022 & $0.052 * * *$ & $0.020 * * *$ & 0.015 & 0.015 & $0.034 * *$ \\
\hline & $(0.015)$ & $(0.014)$ & $(0.015)$ & $(0.006)$ & $(0.011)$ & $(0.012)$ & $(0.014)$ \\
\hline Observations & 9,230 & 9,230 & 9,230 & 9,230 & 9,230 & 9,230 & 9,230 \\
\hline
\end{tabular}

Notes: Table reports average marginal effects for the "major influence" category, estimated after running ordered logit models.

Estimates use balanced repeated replication (BRR) bootstrap population weights. Standard errors in parentheses.

$* * * \mathrm{p}<0.01, * * \mathrm{p}<0.05, * \mathrm{p}<0.1$. 